\title{
Management of Dystocia in Buffalo due to Dicephalus Ischiopagus Tetrabrachius tetrapus Monster Calf
}

\author{
Navjot Singh*, Navgeet Singh, Bilawal Singh and Khushpreet Singh
}

Department of Veterinary Gynaecology and Obstetrics, Guru Angad Dev Veterinary and Animal Sciences University, Ludhiana - 141004, Punjab, India

*Corresponding author

\section{A B S T R A C T}

\section{Keywords}

Buffalo, Dystocia, Ischiopagus

Article Info

Accepted:

17 December 2018

Available Online:

10 January 2019
A malformation in the fetus causes monstrosity which results difficulty in parturition. Fetal anomalies and monstrosities are common causes of dystocia in bovine with the incidence of $7.9 \%$ in riverine buffaloes. The present communication records dystocia in a primiparous buffalo due to ischiopagus monster calf which was relieved through an emergency caesarean section. Various genetic and environmental factors are believed to be responsible for the failure of twins to separate after conception resulting in the formation of a conjoined twin. Present case seemed to be due to non-inherited teratogenic defect during embryonic development with early complete duplication of cranial and caudal parts.

\section{Introduction}

A monster is an individual having multiple anomalies involving many organs and systems of the body and very often these monstrosities are associated with dystocia. Conjoined twins are monozygotic and arise from a single ovum. Depending upon site of fusion and non separation, different types of conjoined twin fetal monsters arise. Various fetal monsters have been reported in cattle but they are reported to a lesser extent in buffaloes. For the obstetrical management of conjoined twins, delivery by cesarean section is usually undertaken (Whitlock et al., 2008). The present report records a rare case of dystocia in buffalo due to ischiopagus monster calf which was relieved through an emergency caesarean section. Though, caesarean section or fetotomy is recommended to relieve this kind of dystocia, nevertheless, the conjoined twin monster fetus in buffaloes has been delivered through caesarean section (Pandey et al., 2013).

\section{Case History and Observations}

A buffalo in first parity having dystocia at full term of gestation was presented at Department of Veterinary Gynaecology and Obstetrics, 
Teaching Veterinary Clinical Complex, GADVASU, Ludhiana. According to the history, water bags had ruptured ten hours ago and animal was straining but the delivery attempts proved futile. Clinical examination at field level gave a clue of presence of monster fetus as reported by owner of animal. Per vaginal examination revealed fully open cervix with two limbs in the birth canal. Deeper exploration was suggestive of fetus being a conjoined twin monster. Hence, the case was diagnosed to be dystocia due to conjoined twin monster and a decision to relieve it through an emergency caesarean section was taken. Fetotomy operation of the presented case required extensive manipulations and per vaginal delivery was not possible, so caesarean section was chosen to be the best option.

\section{Treatment and Discussion}

After properly restraining the animal in right lateral recumbency, it was prepared for surgical intervention. Caesarean section was performed under local in filteration anaesthesia (Lignocaine hydrochloride 2\%, 90 ml) using paramedian approach as per the techniques described by Roberts, 2004. After delivery, it was found that the monster fetus was fused from ischium having two heads, four forelimbs and four hind limbs and accordingly it was named as dicephalusis chiopagus tetrabrachius tetrapus (Fig. 1).

Fig.1 Ischiopagus conjoined twin monster calf

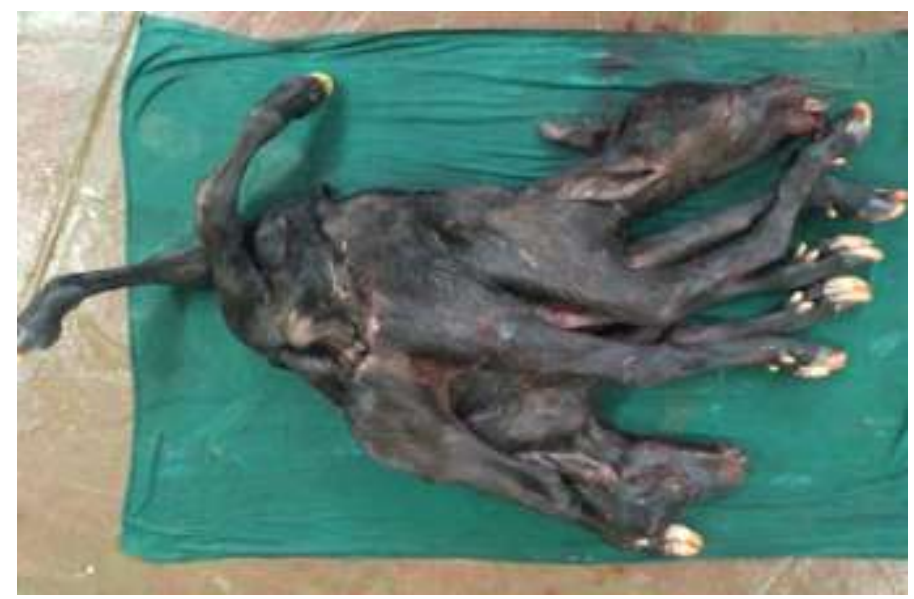

Post-operative treatment included fluid therapy (Normal saline solution 5 litres, IV), antibiotics, anti-inflammatory cum analgesics, rumenatorics and multivitamins for the next 5 days. Antiseptic dressing of the surgical wound was done on alternate days and skin sutures were removed on the day 14 postcesarean section.

Various genetic and environmental factors are believed to be responsible for the failure of twins to separate after conception resulting in the formation of a conjoined twin. Dystocia due to ischiopagus conjoined twin monster in buffalo has been earlier reported by Simon $e t$ $a l$. , (2009).Twins are monozygotic in origin, and due to incomplete division of one embryo into two components usually at the primitive streak development state, monsters are said to occur. Present case seemed to be due to noninherited teratogenic defect during embryonic development with early complete duplication of cranial and caudal parts. Per-vaginal delivery of these conjoined twins seems difficult due to their large size, so caesarean section provides a better option to save life of 
the animal. Performing fetotomy in these type of cases require great amount of manipulations which poses a greater risk on the life of dam as well, so caesarean section is best method for successful delivery of fetus in these type of cases.

\section{References}

Roberts, S.J. (2004). Veterinary Obstetrics and Genital Diseases, 2nd ed. CBS Publishers, New Delhi. India.

Shukla, S.P., U.K. Garg, AnandPandey, D.P. Dwivedi and S.P. Nema. (2007).
Conjoined twin monster in a buffalo. Indian Vet. J.84: 630-31.

Simon, M.S., William, B.J. and Kannan, T.A. (2009). A rare case of conjoined twin monster (Ischiopagus) in a she buffalo. Indian J. Anim. Reprod.30: 90-91.

Whitlock, B., Kaiser, L. and Maxwell, H. (2008) Heritable bovine fetal abnormalities. Theriogenology70: 53549.

Pandey, A.K. and G. Singh. 2012. Dystocia due to dicephalus tetrabrachius ischiopagus tripus di caudatus in buffalo. The Blue Cross Book, 27: 53-54

\section{How to cite this article:}

Navjot Singh, Navgeet Singh, Bilawal Singh and Khushpreet Singh. 2019. Management of Dystocia in Buffalo due to Dicephalus Ischiopagus Tetrabrachius tetrapus Monster Calf. Int.J.Curr.Microbiol.App.Sci. 8(01): 2398-2400. doi: https://doi.org/10.20546/ijcmas.2019.801.252 